\title{
Economic feasibility of grazing sheep on leafy spurge-infested rangeland in Montana
}

\author{
KENT E. WILLIAMS, JOHN R. LACEY, AND BRET E. OLSON
}

\begin{abstract}
Authors are Phillips County extension agent, Malta, Mont. 59538, former extension range management specialist, and associate professor of Range Science, Department of Animal and Range Sciences, Montana State University, Bozeman, Mont. 59717.
\end{abstract}

\begin{abstract}
Leafy spurge (Euphorbia esula $\mathrm{L}_{\text {.) }}$ is a noxious weed on rangelands throughout the Northern Great Plains. Most of these ranges are grazed by cattle which do not use leafy spurge as forage. Although sheep graze leafy spurge, most land managers are reluctant to use sheep to control this noxious weed, which may be related to economic uncertainties regarding their profitability. The purpose of this study was to evaluate the economic feasibility of implementing a sheep enterprise to control leafy spurge on cattle ranches. The physical characteristics of a typical Northern Great Plains ranch, recommended stocking rates for cattle and sheep on native and leafy spurge-infested rangelands, and a sheep enterprise budget were developed using information from the literature. A LOTUS ${ }^{\circledR}$ spreadsheet was developed to calculate returns over total costs of implementing various sheep enterprises. Annual returns from implementing sheep grazing on 520 ha of leafy spurge on a 4,905 ha ranch exceeded total costs by $\$ 4,675$. Given the ownership costs and returns of our ranch, the breakeven lamb price would be $\$ 1.16 \mathrm{~kg}^{-1}$. Returns per head and per unit of land will vary with the distribution and size of a leafy spurge infestation, and sheep production costs and returns. Returns from sheep grazing were higher when leafy spurge was concentrated in fewer rather than in many pastures. Returns were positive when as little as $4 \%$ of the ranch was infested with leafy spurge. The availability and utility of our model will allow land managers to assess the feasibility of developing sheep enterprises to control leafy spurge.
\end{abstract}

Key Words: Euphorbia esula, economic analysis, noxious weeds

Leafy spurge (Euphorbia esula L.), an aggressive, perennial forb from Eurasia infested over 260 thousand ha of rangeland in Montana in the mid-1980s (Lacey et al. 1985), and has increased at least $25 \%$ since that time $(H$. Stepper, personal communication). Invasion of rangelands by leafy spurge has reduced biodiversity (Belcher and Wilson 1989) and land values for livestock grazing, wildlife habitat, and recreation (Leistritz et al. 1992).

We appreciate support from the USDA-SARE Grant "The Sustainability of Range Livestock Systems in Environmentally Sensitive Areas", and the USDA CSRS Grant, "Sheep Grazing-Leafy Spurge: Ecology and Management". We thank D. Griffith, R. Kott, R.Sheley, and G. Surber for reviewing the manuscript. This is published with approval of the Director of the Montana Agricultural Experiment Station, Joumal Series J-3051.

Manuscript accepted: 10 Oct 95.
Leafy spurge is difficult to control on range and pastures, though chemical and mechanical control is effective on small infestations (Fay 1992). These strategies may not be economically or environmentally appropriate over large areas. While environmentally appealing, the effectiveness of establishing and using flea beetles (Apthona spp.) and other biological control agents to control leafy spurge has not been proven.

Previous research has shown that sheep can be used to control leafy spurge (Johnston and Peake 1960, Bowes and Thomas 1978). Although sheep grazing will reduce density and biomass of leafy spurge, eradication is not likely (Lacey et al. 1985), thus sheep should be considered a long term weed management strategy. This may explain why sheep have not been widely used to control leafy spurge (Alley and Messersmith 1985). Most Montana ranchers raise cattle which do not graze leafy spurge. We believe that sheep are not widely used to control leafy spurge because of economic uncertainties, and possibly managerial constraints associated with using sheep.

Information on costs and returns of using sheep to control leafy spurge on cattle ranches is needed. The objective of this study was to evaluate the economic feasibility of grazing sheep to control leafy spurge on eastern Montana cattle ranches. We developed a model incorporating a LOTUS ${ }^{\circledR}$ spreadsheet to compare different scenarios of sheep grazing leafy spurge.

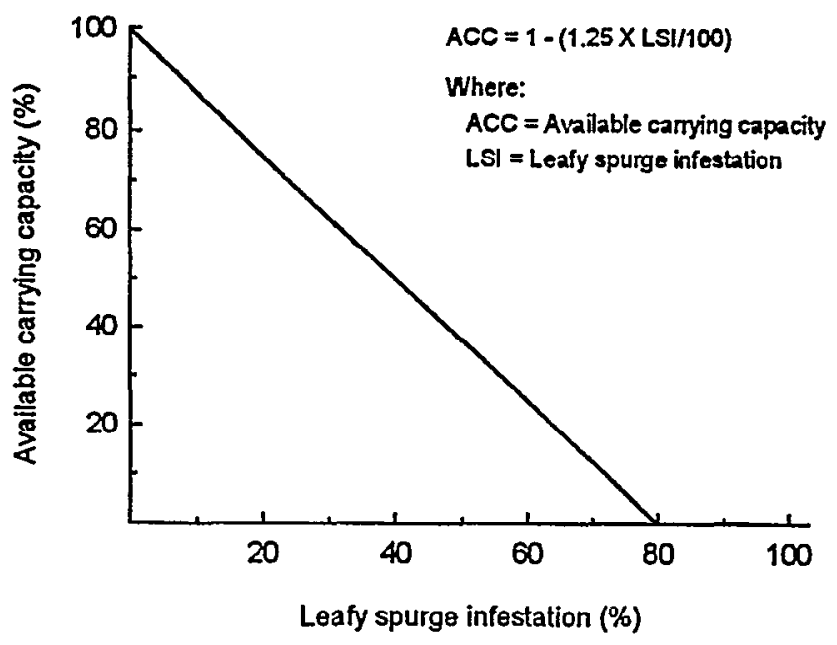

Fig. 1. Influence of leafy spurge infestation on cattle-grazing capacity of rangeland. Adapted from research from North Dakota State University (Leistritz et al. 1992). 
Table 1. Sheep enterprise budget formulated for the Northern Great Plains assuming an average level of management.

\begin{tabular}{lr}
\hline \hline Item & \\
\hline Production characteristics & 140 \\
Percent lamb crop weaned $(\%)$ & 51 \\
Market lamb selling weight $(\mathrm{kg})$ & \\
Income sources & $\$ 73.95$ \\
Lamb sales @ $\$ 1.45 \mathrm{~kg}, 51 \mathrm{~kg}$ & 4.80 \\
Cull ewe $\left(16 \%\right.$ sold @ $\left.\$ 30 \mathrm{hd}^{-1}\right)$ & 10.32 \\
Wool sale $\left(4.3 \mathrm{~kg} @ \$ 2.40 \mathrm{~kg}^{-1}\right)$ & $\$ 89.07$ \\
Total income & \\
Cash costs per ewe & $\$ 11.02$ \\
grain & 19.15 \\
hay & .40 \\
mineral and salt & .51 \\
crop residue & 3.00 \\
supplements & 2.00 \\
health & 4.50 \\
breeding & 2.00 \\
power and fuel & 2.44 \\
shearing & 1.00 \\
marketing & 1.50 \\
machinery & 2.50 \\
labor & 2.00 \\
miscellaneous & $\$ 53.02$ \\
Total cash costs & $\$ 36.05$ \\
Return over variable costs & \\
\hline &
\end{tabular}

\section{Materials and Methods}

The typical ranch in southeastern Montana includes 153 ha of cropland, 328 ha of hay, and 4,484 ha of range, a total of 4,965 ha (Johnson et al. 1994). The ranch has $58 \mathrm{~km}$ of fence. We assumed the rangeland was fenced into 6 equal sized pastures ( $747 \mathrm{ha}$ ).

The typical ranch carries 471 animal units. Based on an 8month grazing season, forage from range supplies 3,530 animal unit months (AUMs). For cattle grazing, the average stocking rate of rangeland that is not infested with leafy spurge is 1.27 ha per AUM. Leafy spurge reduces carrying capacity by suppressing forage production, and limits availability because cattle avoid range sites infested with leafy spurge (Lym and Kirby 1987). We used Leistritz et al.'s (1992) model to estimate the influence of leafy spurge infestations on carrying capacities for cattle (Fig. 1). An infestation covering $60 \%$ of a pasture reduces carrying capacity for cattle by $75 \%$, or to $25 \%$ of its uninfested level. In contrast, sheep readily graze leafy spurge, thus carrying capacities for sheep are unaffected by the level of infestation.

Although leafy spurge density and percent composition varies within plant communities (Selleck et al. 1962), we assumed that leafy spurge composition averaged $50 \%$ throughout infested
Table 2. Input variables and output from using LOTUS $®$ spreadsheet to analyze the economics of controlling leafy spurge with sheep.

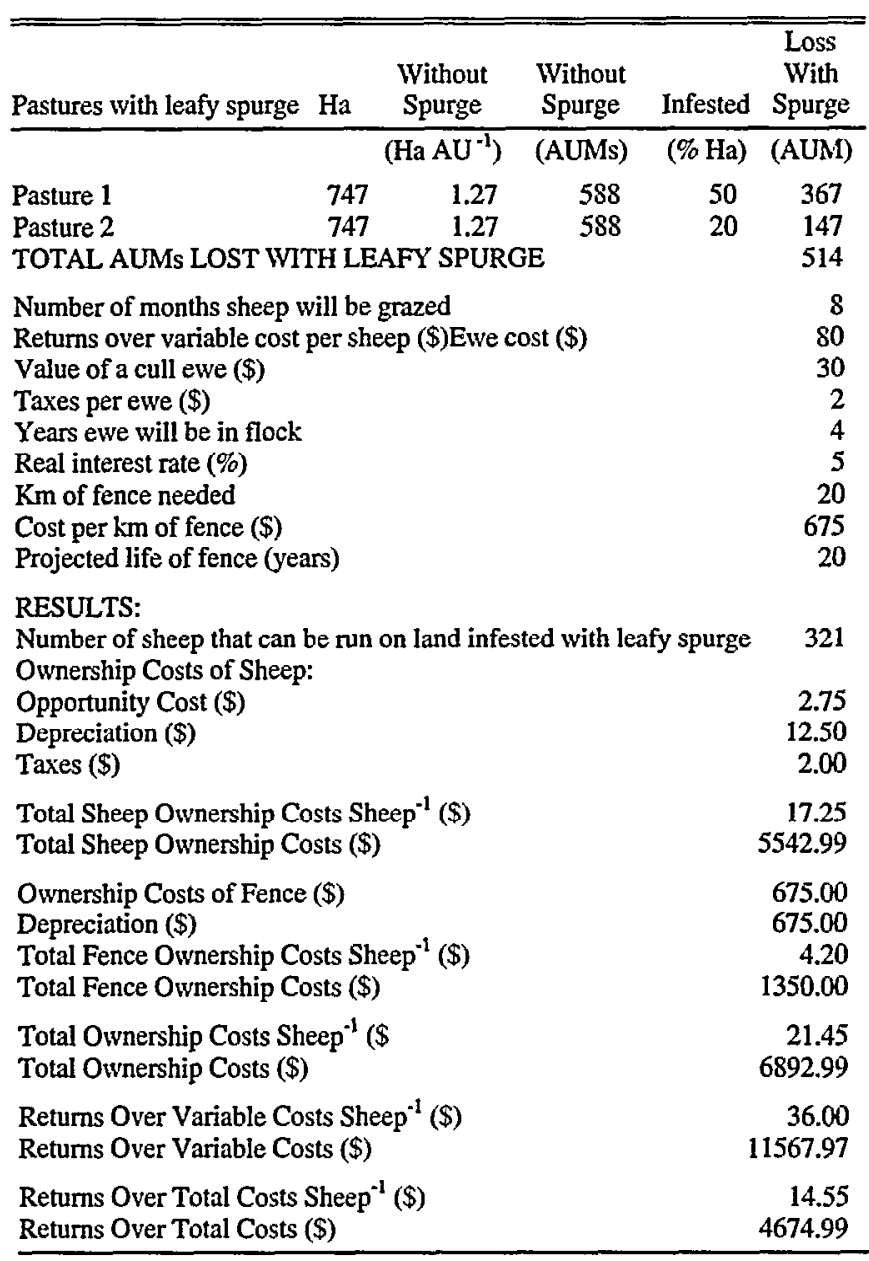

areas. On the basis that leafy spurge makes up to $50 \%$ of a sheep's diet (Landgraf et al. 1984), we assumed that sheep would harvest the available forage within areas infested by leafy spurge (Bartz et al. 1985). Forage growing outside of infested areas but within leafy spurge pastures was assumed to be available to cattle. Sheep were substituted for cattle at the ratio of 5:1, and sheep carrying capacity of leafy spurge-infested rangeland was set at 1.27 ha per AUM.

We developed a sheep enterprise budget from Freeman and Jordan (1990) and a Standardized Production Analysis for sheep (SPA; American Sheep Industry 1994). We estimated returns over variable costs of $\$ 36.05$ per ewe (Table 1 ).

The opportunity costs of implementing a sheep enterprise on

Table 3. Influence of the distribution of leafy spurge among pastures, assuming a constant level of infestation (13\% of the rangeland on a ranch is infested), on the economic feasibility of implementing a sheep enterprise to control the plant.

\begin{tabular}{|c|c|c|c|c|c|c|}
\hline & $\begin{array}{l}1 \text { Pasture } \\
(80 \%)\end{array}$ & $\begin{array}{l}2 \text { Pastures } \\
\text { (40\% each) }\end{array}$ & $\begin{array}{l}\text { 3 Pastures } \\
\text { (27\% each) }\end{array}$ & $\begin{array}{l}\text { 4 Pastures } \\
\text { (20\% each) }\end{array}$ & $\begin{array}{l}5 \text { Pastures } \\
\text { (16\% each) }\end{array}$ & $\begin{array}{c}\text { 6 Pastures } \\
\text { (13\% each) }\end{array}$ \\
\hline \multicolumn{7}{|l|}{ Item } \\
\hline $\begin{array}{l}\text { Sheep (number of head) } \\
\text { Km of fence required } \\
\text { Returns ewe }{ }^{-1} \\
\text { Net Returns (\$) }\end{array}$ & $\begin{array}{c}367 \\
11.3 \\
16.67 \\
6123\end{array}$ & $\begin{array}{c}367 \\
19.4 \\
15.18 \\
5576\end{array}$ & $\begin{array}{c}367 \\
27.4 \\
13.71 \\
5036\end{array}$ & $\begin{array}{c}367 \\
33.9 \\
12.52 \\
4597\end{array}$ & $\begin{array}{c}367 \\
41.9 \\
11.05 \\
4057\end{array}$ & $\begin{array}{c}367 \\
46.8 \\
10.15 \\
3727\end{array}$ \\
\hline
\end{tabular}


Table 4. Relationship between size of leafy spurge infestation within 2 pastures of a 6 pasture ranching operation on the economic returns of implementing a sheep grazing program.

\begin{tabular}{lrrrrrrrrrr}
\hline \hline \% Infestation & 5 & 10 & 15 & 20 & 30 & 40 & 50 & 60 & 70 & 80 \\
\hline Sheep (number of head) & 46 & 9 & 138 & 184 & 275 & 367 & 459 & 551 & 643 & 734 \\
Returns ewe $^{-1}$ & -9.72 & 4.49 & 9.24 & 11.62 & 14.00 & 15.18 & 15.90 & 16.37 & 16.71 & 16.97 \\
Net Retums (\$) & 449 & 412 & 1273 & 2133 & 3855 & 5576 & 7298 & 9019 & 10,740 & 12,462 \\
\hline
\end{tabular}

the typical ranch were estimated. Although we assumed that woven wire would be placed over existing barbed wire fences (around pastures infested with leafy spurge) to contain sheep, another strand of barbed wire or electric fences could be used to reduce fencing costs in many situations. Fencing costs were depreciated over 20 years which reflects that sheep grazing leafy spurge requires a long term commitment. We assumed that the 6 pastures were rectangular ( 2 by 3 pastures arranged in a grid patterm). To fence 1 to 6 of these pastures would require 11.3, 19.4, $27.4,33.9,41.9$, and $46.8 \mathrm{~km}$ of materials, respectively. Woven fence was priced at $\$ 65 \mathrm{roll}^{-1}(100 \mathrm{~m})$. Ewes were purchased at $\$ 80 \mathrm{head}^{-1}$. The opportunity cost of implementing the sheep enterprise was calculated using a real interest rate of $5 \%$ (Watts and Johnson 1985).

The feasibility of grazing sheep to control leafy spurge was evaluated using a model developed on a LOTUS ${ }^{\circledR}$ spreadsheet. Thirteen input variables were entered: total number of ha in each pasture that contain leafy spurge, ha $\mathrm{AUM}^{-1}$ on uninfested range, percent of land within the pasture infested with leafy spurge, the number of months that sheep will be grazed, returns over variable cost per ewe, ewe cost, value of a cull ewe, taxes per ewe, years ewe will be in flock, real interest rate, $\mathrm{km}$ of fence needed, cost per $\mathrm{km}$ of fence, and projected life of fence.

Model output initially lists the number of AUMs without leafy spurge and the AUM loss resulting from the spurge infestation. Results include number of sheep that can be grazed and ownership costs of sheep and fence. The model is available through the Phillips County Extension Office, Malta, Mont. 59538.

\section{Results and Discussion}

Our initial analysis assumed that 2 pastures contained leafy spurge (Table 2). Leafy spurge infested $20 \%$ and $50 \%$ of the land within the 2 pastures, respectively. The infestations reduced cattle grazing by 514 AUMs. With an 8-month grazing season, 321 sheep could graze those pastures infested with leafy spurge.

Ownership costs were $\$ 5,543$ for sheep and $\$ 1,350$ for fencing. Returns over variable costs sheep ${ }^{-1}$ were $\$ 36$. Returns over total costs sheep $\mathrm{p}^{-1}$ were $\$ 14.55$. Thus, for the 321 sheep returns over total costs were $\$ 4,675$. Given these ownership costs and returns, the breakeven lamb price would be $\$ 1.16 \mathrm{~kg}^{-1}$.

The distribution of leafy spurge influences the economic feasibility of using sheep to control the plant (Table 3). If leafy spurge infests $13 \%$ of the land base, total returns are $\$ 6,123$ if the leafy spurge infests only 1 pasture, but are only $\$ 3,727$ if the infestation is spread over 6 pastures. Returns are lower when the infestation is spread over 6 pastures because the costs of implementing sheep grazing are higher with the greater extent of infestation.

The economic feasibility of grazing sheep to control leafy spurge increases as the size of the leafy spurge infestation within a pasture increases (Table 4). Because more sheep are available to pay the opportunity costs of fencing, total returns increase from $-\$ 449$ when $5 \%$ of the 2 pastures are infested, to $\$ 12,462$ when $80 \%$ of the 2 pastures are infested. Sheep grazing yielded positive returns when $10 \%$ of the 2 pastures were infested. Although returns were negative when only $5 \%$ of the pastures were infested, the sheep were being used as a tool for controlling weeds, besides producing wool and lamb. Their costs should be compared with costs of alternative control methods.

Our results provide needed information about the economic feasibility of implementing a sheep enterprise to control leafy spurge on a cattle ranch. Our model could be used to evaluate most conditions in the Northern Great Plains by altering values of input variables. It could then be used to calculate returns over total costs for specific ranch situations.

\section{Literature Cited}

Alley, H. P. and C. G. Messersmith. 1985. Chemical control of leafy spurge. p. 65-78. In: A. K. Watson (ed.), Leafy Spurge Mono. Ser. Weed Sci. Soc. Amer. No. 3, Champaign, Ill.

American Sheep Industry. 1994. Standardized Production Analysis. American Sheep Industry Association, Englewood, Colo.

Bartz, S., B. Landgraf, P. Fay, and K. Havstad. 1985. Leafy spurge (Euphorbia esula) as a forage component for ewes and lambs. SID Research Digest. Winter:39-42.

Belcher, J. W. and S. D. Wilson. 1989. Leafy spurge and the species composition of a mixed-grass prairie. J. Range Manage. 42:172-175.

Bowes, G. G. and A. G. Thomas. 1978. Longevity of leafy spurge seeds in the soil following various control programs. J. Range. Manage. $31: 137-140$.

Fay, P. K. 1992. The role of herbicides in weed management. Western Wildl., Summer Issue.

Freeman, M. L. and R. M. Jordan. 1990. Sheep flock planning guide. Minnesota Extension Serv., Univ. of Minn. 5 p.

Johnson, J. B., W. Zidak, H.A. Smith, and E. Williams. 1994. Economic and financial sustainability of range-livestock operations in the plains region of Montana. Dept. of Agr. Econ. and Econ., Montana State Univ., SR 94-2 46 p.

Johnston, A. and R. W. Peake. 1960. Effect of selective grazing by sheep on the control of leafy spurge (Euphorbia esula L.). J. Range Manage. 13:192-195.

Lacey, C.A., P.K. Fay, R.G. Lym, C.G. Messersmith, B. Maxwell, and H.P. Alley. 1985. The distribution, biology and control of leafy spurge. Mont. State Univ. Coop. Ext. Ser. Circ. 309.

Landgraf, B.K., P.K. Fay, and K.M. Havstad. 1984. Utilization of leafy spurge (Euphorbia esula) by sheep. Weed Sci. 32:348-352.

Leistritz, L. F., A. Bangsund, N. M. Wallace, and J. A. Leitch. 1992. Economic impact of leafy spurge on grazingland and wildland in North Dakota. N. Dakota State I Iniv. AE 92005.14 p.

Lym, R. G. and D. R. Kirby. 1987. Cattle foraging behavior in leafy spurge (Euphorbia esula)- infested rangeland. Weed Tech. 1:314-318.

Selleck, G.W., R.T. Coupland, and C. Frankton. 1962. Leafy spurge in Saskatchewan. Ecol. Mono. 32: 1-29.

Watts, M.J. and J.B. Johnson. 1985. The relationship of inflation to agricultural income, asset values, and firm financial analysis. Staff Papers in Economics. Agr. Econ. and Econ. Dept. Mont. State Univ. SP No. 85-6. 